\title{
Compensating Differentials and the Value of Job Security: Evidence from the Egyptian Public Sector
}

\author{
Mona Said \\ London Middle East Institute, SOAS, University of London
}

$\&$

School of Business, American University in Cairo

Received: July 30, 2011

Accepted: August 11, $2011 \quad$ Published: January 1, 2012

doi:10.5539/ijef.v4n1p56

URL: http://dx.doi.org/10.5539/ijef.v4n1p56

\begin{abstract}
This paper considers the determinants of male and female pay in the public and private sectors by estimating a joint model of sector allocation and wage determination using cross-sectional data from the Egyptian 1987 and 1997 labour force surveys. A model of compensating wage differentials is defined and estimated, in order to quantify the value of arguably the three most important non-pecuniary aspects of public sector employment: job security, fringe benefits (especially comprehensive retirement pensions) and lower effort and shorter hours which allow workers to supplement income through obtaining a second job. Estimates of the public-private differentials, correcting for differences in characteristics and selectivity, indicate a public sector disadvantage for males and a small advantage for females in 1987. Relative public sector wages improved for both males and females in 1997, and when adjustments for non-wage benefits are included, public sector premia are observed in all segments of the public sector for both males and females. The results highlight the importance of job security as the major factor determining the persistence of queues for public sector jobs in Egypt.
\end{abstract}

Keywords: Public sector employment, Job security, Public-private wage differential, Egypt

JEL Classification: J31, J32, J45

\section{Introduction}

As governments attempt to act as model employers, many studies in both industrialized and developing country settings have documented that gender wage gaps tend to be more compressed in the public sector. This led to concerns that the discriminatory component in gender gaps might be more exacerbated by structural adjustment programs and privatization strategies that aim, among other things, to reduce the size of government.

This paper considers the estimation of gender-based and sector-based wage differentials between and within public and private sector labour markets. The Egyptian labour market provides an interesting case study of public-private and gender wage gaps for several reasons. The public sector became the predominant employer in the Egyptian labour market following the wave of nationalisation in the early 1960s. This started the radical shift towards central planning and state-led industrialisation under the Nasser regime in Egypt. It also signalled escalating demand for secondary and higher education and ensuing entry of women in large numbers to formal non-agricultural employment. During that period, a public sector employment guarantee was enacted for all secondary school and university graduates, and public sector compensation and hiring practices constituted the main institutional force governing the operation of the formal labour market. Both mechanisms were more or less gender blind and resulted in an unprecedented increase in female educational attainment, a high degree of preference of women for government employment and relatively compressed gender pay gaps throughout the formal labour market.

The liberalization of the Egyptian economy since the mid-1970s, and particularly the drive towards privatization and trade liberalization in the 1990s and the new millennium, have led to renewed interest in the issue of gender-based employment and pay gaps, amidst signs that the state is clearly retrenching its role as a 'model employer' and 'employer of last resort'. This time, studies have highlighted the rise of substantial gender inequities in wage and job quality and serious regression of female labour force participation in general, particularly over the past decade. For example, the latest UNDP Egypt Human Development Report (2010) indicates that the female labour force participation rate declined to 20 percent in 2009 , after reaching more that 40 percent in the 1990 s. This regression is generally associated with the rise of discriminatory environment against working women as the state seized to provide sufficient employment opportunities for women. 
Previous studies on public-private differentials in Egypt although recognising the central role of non-pecuniary aspects (in particular job security) in determining the continued attractiveness of the public sector jobs, no attempt was made to incorporate the impact of job instability and other non-wage benefits in the empirical estimation of sector-pay gaps. (Note 1)

Based on the use of two micro survey data sets, this paper will attempt to quantify the value of arguably the three most important non-pecuniary aspects of public sector employment: job security, fringe benefits (especially comprehensive retirement pensions) and lower effort and shorter hours which allow workers to supplement income through obtaining a second job. This is accomplished by defining and estimating a model of compensating wage differentials which utilises information on the variability of employment, second job holding and access to pensions and medical insurance in these surveys. The methodology allows for calculating the difference between the public and private sectors in both the incidence and personal (or individual-specific) valuation of these non-wage benefits. This allows for directly ascertaining the role of wage differentials as opposed to non-wage factors in the persistence of the queue for public jobs among males and females.

The rest of this paper is organized as follows, after a brief review of the related literature in Section 2, the theoretical and estimation model, data and variable specifications will be described in Sections 3 and 4 respectively. Section 5 then presents and discusses estimation results and utilizes the model of compensating differentials to adjust public-private wage differentials to non-pecuniary aspects of jobs. Finally, section 6 concludes by discussing some of the policy implications.

\section{Literature Review}

Numerous studies have been previously conducted to compare and analyze the difference between public- and private-sector pay or wages both in advanced and developing countries. Bender (2003) examines the equality of public- and private-sector wage distributions using British SCELI survey data carried out in 1986. It was found that the most important differences when examining the factors contributing the incomparability of wages are differences in the distributions of wages for males and the difference in mean wages for females. The results indicate that males at the low end of the wage distribution in the public-sector are paid more than their private-sector counterparts. However, the results show that those at the high end of the wage distribution in the private-sector make more than their public-sector counterparts.

This double imbalance is not experienced amongst women. Women at the low end of the pay distribution in the public-sector are paid less than those similarly placed in the private-sector. On the other hand women at the high end of the pay distribution in the public-sector are paid more than those similarly placed in the private-sector. Another previous work attempting to explain sectoral differences in the industrialized West was conducted by Disney and Gosling (1998), who offer evidence from the British labour market using microeconomic data from the British Household Panel and General Household Surveys to describe how the distribution of pay differs between the public and private sectors in 1983 and in the early 1990s. They found that women with intermediate-level qualifications do the best in the public- sector. The pay premium once experienced by public-sector workers has severely eroded and has now all but disappeared for men. Furthermore, the more rapid increase in pay inequality in the private-sector (compared to the public-sector) has enhanced the ability of the public-sector to increase pay.

Meanwhile, studies such as Rosen (1986) thoroughly examine Adam Smith's theory of equalizing differences and surveys empirical evidence, whereby workers who suffer from poor working conditions should be paid higher wages. Fairris (1992) found similar results in his study of in pay for hazardous work in union and nonunion settings. It was found that union workers maintain larger compensating payments for more hazardous work compared to their nonunion worker counterparts. Although there are political mechanisms for union workers to bid up compensating payments for hazardous work, there is no assurance that safer working conditions will results. This appears to be evident from the slightly higher injury rate experienced by union workers. In a slightly different context, Lanfranchi et al (2001) studies whether French male blue collar workers are being compensated for their shift work, but also looks at whether the French worker engages in shift work to receive high compensating wages, or because he prefers shift work. Two main results of the study reveal that the wage rate for shift workers is 16 percent higher than that for full-time workers. Another result is that shift choice is responsible for determining wage differentials and not shift preferences.

Public sector restructuring and privatization have caused substantial labour retrenchment in many countries, and displaced workers often suffer welfare losses. While these losses were slightly alleviated by retaining programs and job search assistance, severance programs proved to be one of the most effective methods, though expensive and often over-paying workers relative to their welfare loss. In his study of severance programs and workers' loss in the Egyptian public sector, Assaad (1999) compares the earnings of workers in and out of public enterprise, while taking 
account of differences in non-wage benefits and non-random sector selection. He also relates workers' losses to observable characteristics such as seniority, age, educational attainment, and gender, and assesses how well alternative redundancy pay formulas typically used in severance programs match compensation payments to these estimated losses. Results of Assaad's study show that women more than men tend to face strong barriers to entry into wage jobs in the private sector, and thus have poorer earning prospects there, having significantly higher losses than men. Abdelhamid and El Baradei (2009) address what needs to be done to reform the pay system for government employees in Egypt through proposing a concrete set of feasible policy solutions and strategies. The study highlights an urgent need for attrition, retention, replacement, redeployment, and capacity building in government staff, as much as for salary and wage revision. A strategic civil service reform plan was proposed in this study mainly focusing on five issues which are: the availability of extra funding necessary for increasing government employees' pay; the decentralization of the government civil service; a reduction of wage discrepancies and establishing a more transparent allowance system; the reform of wage policy; and establishing a better link between pay and performance.

In Egypt the need for understanding its labour market and how it operates is essential for effective planning. Lifetime social contract between the government and government workers in Egypt raises the need for understanding the preferences and determinants for early retirement among government workers. El-Hamidi (2010) notes that older government workers are normally paid more than younger workers and this pay is not always congruent with their productivity. As a result, losing older workers through early retirement can save the government money. However, Assaad (1999) found that severance packages to entice early retirement among government workers are no match to the welfare losses actually faced by employees, as voluntary severance packages tend to over-pay workers. Building from this review the following analysis demonstrates how models based on a compensating differentials hypothesis can estimate the value of job security and its central role in segmenting the Egyptian labor market today.

\section{Estimation Model}

The model underlying the estimation in this paper employs a variant of Heckman's two-step procedure whereby the wage equations are estimated simultaneously using maximum likelihood methods.

Wages in the two sectors are postulated to be determined by the following system of two equations:

$$
\operatorname{Ln} \mathrm{W}_{\mathrm{si}}=\beta_{\mathrm{si}} \mathrm{X}_{\mathrm{i}}+\varepsilon_{\mathrm{si}}(\mathrm{s}=\mathrm{p}, \mathrm{r})
$$

where $\mathrm{Ln} \mathrm{W}_{\mathrm{si}}$ is $\log$ hourly wages in the public (p) or private sectors (r) for individual i, X is the vector of personal and job-related characteristics seen to be of relevance to wage determination and $\varepsilon$ is the random error term. To simplify the presentation, the subscript i will be dropped in the rest of the model.

In calculating public-private total compensation (as opposed to just wage) differentials, it is important to correct for the higher degree of job security in the public sector and the presence of substantial non-wage benefits in some public and private jobs. There are limited attempts in the literature to correct public-private wage differentials for non-pecuniary aspects. This, in large part, may be due to the unavailability of such information in actual data sets. So either one has to rely on extraneous information, (Note 2) or alternatively devise a method of extracting it in an indirect fashion from the same data set, which usually entails making several stringent assumptions.

In this section, a more direct method for evaluating these benefits is proposed which is based on the argument that although an institutional public sector wage setting is unlikely to include pay compensating differentials for non-pecuniary aspects of jobs, the private sector (operating in a more competitive environment) is expected to so. (Note 3) In particular, it is likely to compensate workers in form of higher wages for lack of desirable work conditions and job characteristics. Using an extended earnings equation, it is possible to obtain estimates of such premia due to absence of aspects such as employment stability, access to pensions and medical insurance and long and intensive work day which prevents them from supplementing their income through second job holding. By subtracting these premiums from private sector wages in calculating the public-private differential, one is able to compare similar jobs in terms of non-pecuniary aspects of jobs.

In models of compensating wage differentials, theoretical support for the expected sign on the estimated wage differential associated with non-pecuniary job characteristics, is usually drawn from simple models of utility maximisation. In our case, workers are assumed to derive utility (U) from both wage and non-wage aspects of the job. Institutional aspects of public sector employment in the Egyptian case are likely to consist mainly of job security (or stability), fringe benefits and the possibility of supplementing ones income through holding secondary jobs. This leads to the following representation of a worker's utility function. (Note 4 )

$$
\mathrm{U}=\mathrm{U}(\mathrm{W}, \mathrm{N})=\mathrm{U}(\mathrm{W}, \mathrm{I}, \mathrm{B}, \mathrm{S})
$$

where W represents the worker's wages and $\mathrm{N}$ non wage aspects of jobs. These include: I, a measure of uncertainty or job instability; $\mathrm{B}$, fringe benefits such as pensions and medical insurance and $\mathrm{S}$, the probability of holding a second 
(secondary) job for a given first (or primary) job. The typical assumptions that utility is increasing in desirable attributes and decreasing in undesirable ones are made (i.e. $U_{W}>0, U_{I}<0, U B>0$ and $U_{S}>0$ ).

Thus, workers in the private sector are assumed to receive wage premiums or compensating differentials for a lack of desirable job characteristics such as employment stability, fringe benefits (pensions and medical insurance) and low effort requirement (or short effective working hours) which allows for second job holding. This leads to a representation of wage setting in the private sector in form of the following extended wage function

$$
\operatorname{Ln} \mathrm{W}_{\mathrm{i}}=\mathrm{a}_{0}+\sum^{n} a_{j} X_{i j}+\mathrm{b} \mathrm{I}_{\mathrm{i}}+\mathrm{c} \mathrm{B} \mathrm{B}_{\mathrm{i}}+\mathrm{dS}_{\mathrm{i}}+\mathrm{e}_{\mathrm{i}}
$$

where $L n W_{i}$ is the log of hourly wages for individual $i$; $a_{0}$ is a constant term, $X_{i j}$ are personal and job related characteristics and $a_{j}$ are $K$ parameters that capture their effects on wage setting; and $b$, c, and $d$ are the compensating differentials for earnings instability, fringe benefits and probability of second job holding for a given job respectively.

From the first order conditions of the Lagrangian yielded by maximizing (2) subject to (3), it can be shown that:

$$
\begin{aligned}
& \mathrm{b}=-\mathrm{U}_{\mathrm{I}} / \mathrm{U}_{\mathrm{W}}>0 \\
& \mathrm{c}=-\mathrm{U}_{\mathrm{B}} / \mathrm{U}_{\mathrm{W}}<0 \\
& \mathrm{~d}=-\mathrm{U}_{\mathrm{S}} / \mathrm{U}_{\mathrm{W}}<0
\end{aligned}
$$

At the mean of the sample, the adjusted public-private total compensation premium (or disadvantage) in log terms can be calculated by subtracting private sector wage and non-wage compensating payments from public sector ones as follows:

$$
A D 1=\left(\overline{\ln W_{p}}-\overline{\ln W_{r}}\right)-\left[b\left(\bar{I}_{p}-\bar{I}_{r}\right)+c\left(\bar{B}_{p}-\bar{B}_{r}\right)+d\left(\bar{S}_{p}-\bar{S}_{r}\right)\right]
$$

$\mathrm{AD} 1$ refers to adjusted public-private wage differential number 1 (to be distinguished from AD2 or adjusted public-private wage differential number 2, which will be discussed below). The bar above a variable refers to its mean. Thus $\overline{\ln W_{p}}$ is the mean $\log$ hourly wage of public sector employees in the public sector and $\overline{\ln W_{r}}$ is the mean $\log$ hourly wage of public sector employees if they were rewarded in same manner as comparable private sector employees. (Note 5) Thus the first term in the equation (4) measures the public-private wage premium for the average worker corrected for differences in personal and job characteristics. The second term adjusts the average premium for differences in the level of job instability between the two sectors. The third term adjusts for differences in fringe benefits and the fourth term adjusts for differences in probability of second job holding which allows for supplementing one's income.

To sum up, using the above methodology which assumes competitive behaviour in the private sector and hence payment of compensating wage differentials for the absence of desirable job attributes, it is possible to utilize information on the incidence (not value) of fringe benefits, second job holding, employment stability as well as the individual's household characteristics to obtain a direct estimate of the public-private differential in total rewards (as opposed to just a pay differential). The advantage of this methodology is that, unlike previous attempts in the literature, it does not have to rely on extraneous information and uses information commonly supplied in labour market surveys of this kind in getting an objective estimate of the value of non-wage rewards of jobs. It also does not rely on any strong assumptions regarding the constancy or proportionality of non-wage benefits to wages in the public or private sectors.

The validity of estimates obtained from this methodology, however, relies on the correct measurement of variables included in the compensating differential equation. (Note 6) There are also other factors that can arguably lead to an under-estimation of the magnitude of the required adjustment for non-wage benefits. For example, the possibility that there are other unmeasured non-pecuniary aspects, besides the ones considered here, cannot be excluded. Moreover, the fact that public sector employees tend to be more risk averse than their private sector counterparts may indicate that they value benefits such as job security more dearly than their private sector counterparts. (Note 7) For those reasons, therefore, we interpret the adjustment yielded by AD1 as providing a lower bound on the magnitude of non-wage benefits. We also compute and report, for comparative purposes, an alternative adjustment AD2. This implements a simplified version of the Assaad (1997b) methodology that, subject to his assumptions discussed above, can be taken to provide a more comprehensive (and aggregate) estimate of non-wage benefits.

\section{Data and Variable Specification}

This paper utilizes two separate but comparable micro survey data sets on Egypt: the December round of the 1987 Egyptian Labor Force Sample Survey (henceforth, 1987 LFSS) conducted by CAPMAS and the 1997 Egypt Integrated Household Survey (henceforth 1997 EIHS), undertaken by the International Food Policy Research Institute (IFPRI). The 1987 LFSS survey covers 12,000 households and about 61,000 observations. The 1997 EIHS was 
conducted along the same lines as the World Bank Living Standard Surveys. Besides wage employment, the survey covers a wide variety of topics such as subsidized and other food expenses, health and maternity history, farming and livestock ownership, non-farm family enterprises, credit and savings, and sources of income of households. One major difference between the two surveys is in the way in which wages are inquired about. In order for them to be comparable, we use hourly wages in both cases and do not include fringe benefits or payment in kind.

Log hourly wages are postulated to be a function of human capital variables and regional dummies, including experience (calculated as age minus the number of years of schooling minus the age of entry into school) Also wages are expected to be influenced by job-related characteristics such as whether work is of a casual nature and eight dummy variables for industry or sector of economic activity of the job (agriculture being the omitted category). (Note 8)

\section{Estimation Results}

\subsection{Selectivity-corrected Wage Equations and Public-Private Wage Differentials}

Tables 1 and 2 present estimates from the sector choice probit model and earnings functions in the public and private sectors using the 1987 and 1997 data sets respectively. The MLE estimates, shown in Tables 1 and 2, confirm the presence of sample selection bias. (Note 9) Parameter estimates of the sample selection terms show that in 1987 there was positive selection in the public sector for both males and females, implying that the unobserved characteristics that increase the probability of public sector employment also had a positive impact on wages. There was also positive selection in the private sector for females. In 1997, this was no longer the case as there was more of a random selection in the public sector. Both male and female workers with higher productivity than average are selected in the private sector. This is consistent with the weakening impact of the public sector employment guarantee on the labour market.

The results also show that labour market experience is highly significant in both its linear and quadratic terms. The wage experience profile is steeper in the public sector, implying a higher impact for an additional year of experience in the public than in the private sector. There is, however, a more (concave) curvature in the wage-experience profile in the private sector. This is clearly demonstrated in Figure 1, which shows the predicted wage-experience profile for the reference worker (Note 10) for the two years under study. Although it was not possible to distinguish between the two segments of the public sector (public enterprises and the government) in estimating the wage-experience profile, the results are presented for manufacturing and social services separately. This can give an indication of differences in wage setting between the two as the bulk of employment in the government is in social services and that in public enterprises is in manufacturing in Egypt.

The figure also shows that in 1987, after correcting for the level of education, regional and job related characteristics, there was still a considerable wage gap in favour of the private sector for males in Egypt with less than 30 years of experience. Afterwards, wages were higher in the public sector. This pattern was the case in both manufacturing and social services, except the wage-experience profile is slightly higher in the former sector. For females, the wage gap in favour of the private sector existed but was much smaller for females in manufacturing. In social services, because of the significant returns to seniority, the gap turned into a positive differential in favour of the public sector for more experienced females (more than 20 years of experience). In 1997, the same results on the steepness and curvature of the wage-experience profiles in the two sectors were still held, but now public wages are higher in the public than private sectors for females at all experience levels in both manufacturing and social services. They were also higher for males with more than 10 years of experience in manufacturing (public enterprises) and with more than 30 years of experience in social services (government).

As for the impact of the educational variables on wage determination, it can be seen from the results in the tables that in both years returns to education were higher in the public than in the private sector. In 1987, returns to education were also higher for females than males in both sectors. The situation was reversed in 1997, with returns to education higher for males than females. Only some of the coefficients on the regional dummies were significant and they generally showed that public sector employees whose residence is outside metropolitan areas had a wage premium. In contrast, private sector employees whose residence is out of cities had an earnings disadvantage. The coefficients on industry dummies were mostly insignificant for females due to small sample size in some industries. For males, industry variables turn out to be more relevant in the public sector, implying that within public sector pay differences do not necessarily reflect human capital factors as they do in the private sector.

Based on the wage equation estimates, predicted mean public-private wage differentials (corrected for differences in characteristics) are presented in Table 3 across levels of educational attainment for 1987 and 1997. The figures show that after correcting for differences in characteristics and selectivity, in 1987 there was an average earnings disadvantage for male public sector employees in Egypt when compared to their private sector counterparts 
(amounting to around $44 \%$ of public sector wages). Females on the other hand, had a small earnings advantage or public sector wage premium (around 10\%), mainly due to their advantage in social services.

In 1997, the males disadvantage in manufacturing turned to an advantage of $9 \%$ and it was reduced in social services to -10 percent. On average, Males had a 10 percent pay disadvantage in the public sector. Females, on the other hand, had clear and large wage premiums (on average 93 percent) at all educational levels in the public sector. Unlike males, premiums were higher in social services than in manufacturing. In other words, the comparison of the results from the two years indicates that relative earnings in the public sector have improved for both males and females when compared to 1987. Males still face a small disadvantage in social services (government), but now earn pay premiums in manufacturing (public enterprises). Females have pay advantages in both segments of the public sector, but these are much larger in social services (government).

\subsection{The Probability of Second Job Holding}

To examine the determinants of second job holding, a probit equation is estimated in which the dependent variable equals one if the person has a second job and equals zero otherwise. Second job holding is postulated to be dependent on age, years of schooling, region of residence, industry and gender. A dummy variable is also included to indicate whether a person is a public sector employee or not. The marginal coefficient to that variable captures the difference in the probability of second job holding between the public and private sectors and thus can be used directly in the adjustment for non-wage benefits in equation (4).

The estimation results presented in Table 4 generally confirm the expectation that the probability of holding a second job increases with age and has a concave shape (i.e. the phenomenon is concentrated in middle age groups who tend to have high levels of family responsibility). It decreases with years of schooling and is less likely for females. Residents of lower Egypt (compared to metropolitan areas) and those working in agriculture, social services and the electricity sector are the most likely to hold second jobs. Finally, being a public sector employee is a very significant determinant and it increases the probability of second job holding by 7.2 percent when compared to the private sector employee.

\subsection{Compensating Differentials and the Adjusted Public-Private Wage Differentials}

Finally, in order to implement the adjustment in equation (4), a compensating differential equation for the private sector (similar to equation 3 above) is estimated. Due to the lack of information on the more important and specific benefits for females (maternity leave, unpaid leave to join husband abroad, etc.), the estimation of the equation and hence the adjustment to the differential is limited to males. Since females appear in practice to have an even higher preference for the public sector, on can safely assume that the adjustment for males also represents a lower bound for females.

As the impact of age and level of educational attainment is similar to the previous estimates, comments will be limited to the three additional variables introduced to capture non-pecuniary aspects of the job. Job instability was measured as the coefficient of variation of number of days worked per year. Fringe benefits were denoted by a dummy that was equal to one if the individual had access to pensions, medical insurance and employee provident funds on the job. And probability of second job holding is predicted from the equation estimates above at the mean individual characteristics but for given job characteristics (industry, sector and region).

Note that there is an element of arbitrariness in the measurement of all of those non-pecuniary aspects. Second job holding is widely believed to be under-reported in surveys like this, due to its illegality in some cases in the public sector or the general reluctance of respondents to report sources of supplementary income. Also the list of fringe benefits reported above is not exhaustive. Subsidised clothing, housing, food and enforcement of maternity leave policy etc. are additional benefits widely offered in the public sector but not measured in the 1997 survey. Finally, the variation in number of days worked per year by industry/region is only one amongst many possible measures of job security and may reflect differences in the requirements of jobs rather than their instability. This survey, however, does a better job than others in the Egyptian case in inquiring about the information needed to construct these three variables that can at least give an indication of the extent of coverage of non-pecuniary benefits in the public and private sectors. The parameter estimates for the three variables were all highly significant and had the expected signs. They indicate that for every unit increase in the variation of employment, hourly wages in the private sector increase by $0.5 \log$ points. If probability of second job holding increases by 1 percent, $\log$ wages decrease by 0.01 . And presence of fringe benefits decreases wages in the private sector by $0.12 \log$ points.

These estimates can be used to present an adjustment of the wage differential, which corresponds to AD1 above. A second adjustment AD2 is presented which is comparable to Assaad (1997b) and is based on identifying the marginal workers in the public sector and assuming their rents (including non-wage benefits) are at least equal to zero. This 
yields a lower bound on the proportion of non-wage benefits to public sector wages that is used to adjust the mean wage differential. (Note 11)

The results of those two adjustments are presented in Table 5 for males at the mean of experience and other attributes in the sample, but at different levels of educational attainment. The figures show that the adjustment for fringe benefits and the probability of second job holding increases the wage differentials by 18 percent in manufacturing and by 19 percent in social services. The adjustment for instability is higher for lower educated groups, and also higher in manufacturing than in social services. This is indicative of the high turnover in manufacturing in the private sector. For all sectors of economic activity, the adjustment increases the premium from -10 to 42 percent. Somewhat higher estimates were obtained using Assaad's methodology (AD2). The marginal workers were identified as primary school leavers located in trade who has a disadvantage of 67 percent in the public sector. Assuming these workers are making at least zero rents in order for them to still wish to remain in the public sector, then the figure represents the proportion of non-wage benefits to wage benefits for this group of workers. Under the assumption that this proportion is constant for employees this can be used to adjust the mean public-private wage differential so it is equal to 57 percent of public wages. (Note 12)

To sum up, the adjustment for non-pecuniary benefits enhances the manufacturing (public enterprise) wage more than it does to social services (government). For all sectors of economic activity, the adjustment employing different methodologies yields an estimate of the public-private differential for males in the range of 42-57 percent in 1997. Due to the lack of information on female specific benefits, the adjustment to the differential was limited to males. But since females appear in practice to have an even higher preference for the public sector, the above adjustment for males may be taken to represent also a lower bound estimate for females. In general, due to the reasons cited in Section 3 above, the present adjustments may still underestimate the magnitude of the actual public sector advantage in non-wage benefits. But this, arguably, can be the case with all measures of non-wage benefits, including ones that directly ask each individual to evaluate them in monetary terms. It is argued here that given the importance of non-pecuniary aspects in the overall public-sector compensation package, it is still important to incorporate whatever information is available about them in analyses of public-private wage differentials but perhaps interpret them only as partial adjustments.

\section{Conclusion}

This Paper considers the determinants of male and female pay in the public and private sectors by estimating a joint model of sector allocation and wage determination using cross-sectional data from the Egyptian 1987 and 1997 labour force surveys. The estimates of wage equations themselves show that returns to age and education are higher in the public than in the private sector and residence outside metropolitan areas is associated with a premium in the public sector. Moreover, for males, industry variables turn out to be more relevant in the public sector, implying that within-sector pay differences do not necessarily reflect human capital factors as they do in the private sector. All these results are in line with institutional wage setting in the public sector, the reliance of basic wages setting on the level of educational attainment and increments on seniority as well as the payment of allowances for work outside the city.

Estimates of the public-private differentials, correcting for differences in characteristics and selectivity, indicate a public sector disadvantage for males and a small advantage for females in 1987. The result on the coexistence of male disadvantages with female advantages in the public sector are consistent with those obtained in previous studies on Egypt, Jordan, UK and Germany. The magnitude of the male disadvantage obtained here for 1987 is also close to the results obtained by Assaad (1997a) for 1988.

A model of compensating wage differentials is then defined and estimated, in order to quantify the value of arguably the three most important non-pecuniary aspects of public sector employment: job security, fringe benefits (especially comprehensive retirement pensions) and low er effort and shorter hours which allow workers to supplement income through obtaining a second job. Estimates of the public-private differentials, correcting for differences in characteristics and selectivity, indicate a public sector disadvantage for males and a small advantage for females in 1987. Relative public sector wages improved for both males and females in 1997, and when adjustments for non-wage benefits are included, public sector premia are observed in all segments of the public sector for both males and females.

It also emerged that the single most important adjustment factor leading to the change in the differential is the value of job stability, which drives up the differential in favour of the public sector, particularly in manufacturing. The results highlight the importance of job security as the major factor determining the persistence of queues for public sector jobs in Egypt. Relative public sector wages improved for both males and females in 1997, and when adjustments for non-wage benefits are included, public sector premia are observed in all segments of the public sector. It also emerged 
that the single most important adjustment factor leading to the change in the differential is the value of job stability, which drives up the differential in favour of the public sector, particularly in manufacturing.

The findings of this paper along with several others that reveal a public sector salary disadvantage call attention to dire efficiency issues in the Egyptian public sector. It is unlikely that workers, especially at the higher end of the wage structure, would remain in the civil service, unless they believe the non-wage benefits (mainly job security and low effort) of the job compensate for low wages. Alternatively, they may hold on to the job while having a second job in the private sector or supplementing income through petty corruption and bribery etc. Either way, we have an adverse selection story of low productivity, less motivated workers only interested in securing some minimum income, with minimum effort, from government jobs or using public office to provide access to other types of jobs or bribes. The detrimental impact on productivity and the delivery of public service is well documented in the various studies of the Egyptian bureaucracy. There is an urgent need therefore to review overall compensation policies, especially in the civil service, and particularly discontinue the passive policy of using overall real pay erosion (or wage bill freezes) to reduce over-staffing. For one thing, it does not seem to have worked, given that many workers choose government work for non-pecuniary reasons.

\section{References}

Abdelhamid, D. El Baradei, L. (2009). Reforming The Pay System For Government Employees in Egypt. The Egyptian Center for Economic Studies Working Paper Series WP151, 1-41. Available at: http://www.eip.gov.eg/Upload/Publications/REFORMING\%20THE\%20PAY\%20SYSTEM\%20FOR\%20GOVERN MENT.pdf

Aslam, M., \& Kingdon, G. (2009). Public-Private Sector Segmentation in the Pakistani Labour Market. Journal of Asian Economics, 34-49. Available at ScienceDirect: http://www.sciencedirect.com/science/article/pii/S1049007808000651

Assaad, R. (1997a). The Effects of Public Sector Hiring and Compensation Policies on the Egyptian Labour Market. The World Bank Economic Review, 11.

Assaad, R. (1997b). An Analysis of Compensation Programs for Redundant Workers in Egyptian Public Enterprise. Economic Research Forum Working Paper No. 9701, Cairo. Available at: http://ideas.repec.org/p/erg/wpaper/9701.html

Assaad, R. (1999). Matching Severance Payments with Worker Losses in the Egyptian Public Sector. World Bank Economic Review. Oxford Journals.13(1), 117-153. Available at Oxford Journals: http://wber.oxfordjournals.org/content/13/1/117.abstract

Bellante, D., \& Long, J. (1981). The Political Economy of Rent-Seeking Society: The Case of Public Sector Employees and their Unions. Journal of Labour Research, 2, 1-13. http://dx.doi.org/10.1007/BF02685118

Bellante, D., \& Link, A. (1982). Worker Responses to a Menu of Implicit Contracts. Industrial and Labour Relations Review, 35, 590-599. http://dx.doi.org/10.2307/2522670

Bender, K. (2003). Examining Equality between Public- and Private-Sector Wage Distributions. Economic Inquiry, 41(1) 62-79. http://dx.doi.org/10.1093/ei/41.1.62

Central Agency for Public Mobilisation and Statistics. (1990). Results of the Labour Force Sample Survey, Fourth Quarter 1988: Detailed Employment Characteristics. Labour Information System Project, CAPMAS, Cairo.

Disney, R., \& Gosling, A. (1998). Does It Pay to Work in the Public Sector?. Fiscal Studies, 19(4), 347-374. Available at Wiley: http://onlinelibrary.wiley.com/doi/10.1111/j.1475-5890.1998.tb00291.x/abstract

El-Essawi, I. (2007). The Egyptian Economy in Thirty Years. Cairo, Egypt: Al-Academia Bookshop.

El-Hamidi, F. (2010). Early Retirement in the Government Sector in Egypt: Preferences, Determinants, and Policy Implications. The Journal of Developing Areas, 43(2), 79-110. Available at Project Muse: http://muse.jhu.edu/journals/journal_of_developing_areas/v043/43.2.el-hamidi.html

Fairris, D. (1992). Compensating Payments and Hazardous Work in Union and Nonunion Settings. Journal of Labor Research, 13(2). 205-221. Available at SpringerLink: http://www.springerlink.com/content/f08k67t7242540q7/

Feinberg, R. (1981). Earnings-Risk as a Compensating Differential. Southern Economic Journal, 48, 156-163. Available at JSTOR: http://www.jstor.org/pss/1058607

Glinskaya, E., \& Lokshin, M. (2007). Wage Differentials between the Public and Private Sectors in India. Journal of International Development, 14, 333-355. Available at Wiley: http://onlinelibrary.wiley.com/doi/10.1002/jid.1326/abstract 
Heckman, J. (1976). The Common Structure of Statistical Models of Truncation, Sample Selection and Limited Dependent Variables and a Simpler Estimator for Such Models. Annals of Social Measurement, 5, 475-492.

Heckman, J. (1979). Sample Selection as Specification Error. Econometrica, 47, 153-161. Available at JSTOR: http://www.jstor.org/pss/1912352

Heller, P.S., \& Tait, A. (1983). Government Employment and Pay: Some International Comparisons. IMF Occasional Paper No. 24. Washington, D.C.: IMF.

Lanfranchi, J. Ohlsson, H., \& Skali, A. (2001). Compensating Wage Differentials and Shift Work Preferences, Evidence from France. International Journal of Research in Economics, 1-23.

McGoldrick, K. (1995). Do Women Receive Compensating Wages for Earning Uncertainty?. Southern Economic Journal, 62.

Nawata, K. (1993). A Note on the Estimation of Models with Sample Selection Bias. Economic Letters, 42, 15-24. Available at ScienceDirect: http://www.sciencedirect.com/science/article/pii/016517659390167B

Ramsey, J. (1969). Tests of Specification Errors in Classical Linear Least Square Regression Analysis. Journal of the Royal Statistical Society, Serie B, 31, 350-371

Rosen, S. (1986). The Theory of Equalising Differences. In O. Ashenfelter and R. Layard (Eds.). Handbook of Labour Economics, Amsterdam: North-Holland. Available at JSTOR: http://www.jstor.org/pss/2984219

Shaban, R. Assaad, R., \& Al-Qudsi,S. (1993). Labour Markets in Arab Countries: A Survey, Paper presented to the First Annual Conference on Development Economics, Initiative to Encourage Economic Research in the Middle East and North Africa, Cairo, June 4-6.

UNDP. (2010). Egyptian Human Development Report: Youth in Egypt, Building Our Future. Cairo: UNDP.

\section{Notes}

Note 1. With the exception of Assaad (1997b), who provided a useful methodology to quantify such benefits. The method, however, was based on several restrictive assumptions and only provided a total figure of such benefits without distinguishing between their different components (such as job security, pension schemes, low effort etc.). See Section 3 for details.

Note 2. See Bellante and Long (1981) for an example of a study using extraneous information on public-private differences in the rate of unemployment and fringe benefits to adjust pay differentials for differences in job security and fringe benefits.

Note 3. In the theory of compensating differentials (see Rosen, 1986 for a comprehensive survey), competitive behaviour of firms in the labour market is an important underlying assumption. But that term 'competitive labour market' does not have to refer to a 'perfectly competitive labour market.' It is only assumed that there are many firms who compete for workers and many workers who compete for jobs (Fehr et al., 1994, p. 325)

Note 4. The presentation of the utility and wage functions here are similar to McGoldrick (1995) and Bellante and Link (1982).

Note 5 . This is calculated by predicting log hourly wages for the sub-sample of public sector employees using the private sector parameter estimates.

Note 6. Given the arbitrariness of the manner in which variables such as job stability are measured, the results obtained can best be interpreted as suggestive of the impact of adjusting public-private differentials for non-wage benefits, and not as providing precise estimates of the magnitude of such an adjustment.

Note 7. The rationale here is similar to the analysis of sorting equilibria in the occupational safety and health literature. The operation of a competitive labour market results in sorting workers, with danger-averse ones picking safer jobs and thereby lowering the implicit premium that employers must pay in wages in return for offering dangerous jobs (See Filer et. al, 2000, pp. 381-382). In the present analysis, more risk averse worker choose secure public sector jobs which lowers the compensating differential that the competitive private sector must pay to convince workers to accept less secure jobs.

Note 8. Although the relationship between wage and industrial structure is thought to be complex (see Ryan, 1986 and Gross, 1990), roughly speaking the inclusion of these variables can be thought of as capturing some employer-side influences on wages such as differences in organisational structure, volatility of product demand and differences in product market conditions (Rees and Shah, 1995).

Note 9. As shown in Tables 1 and 2, Ramsey (1969) RESET specification tests rejected the null hypothesis of correct specification (no omitted variables) at the $1 \%$ level of significance for both the male and female equations in 1987 and for the female (but not the male) equation in 1997. 
Note 10. The reference worker is a permanent one holding an intermediate or vocational secondary school certificate and residing in a metropolitan area.

Note 11. The marginal worker is defined as one with the largest negative public-private wage differential. Like Assaad (1997b), we limit this to workers in the beginning of their career (i.e. less than 35 years in age) as it is likely to be much more difficult for workers with a long tenure to change sectors.

Note 12. In calculating rents, Assaad (1997b) also integrated over the life time of workers. We use only the observed differential in 1997, as the author himself noted, the rank between this differential and the difference between the lifetime earnings for public and private employees is likely to be very similar.

Table 1. Maximum Likelihood (Probit) Estimates of the Selection and Wage Equations 1987

\begin{tabular}{|c|c|c|c|c|c|c|c|c|c|c|c|c|c|c|c|c|}
\hline \multirow{3}{*}{ Variable } & \multicolumn{8}{|c|}{ MALES } & \multicolumn{8}{|c|}{ FEMALES } \\
\hline & \multicolumn{3}{|c|}{ Public } & \multicolumn{4}{|c|}{ Private } & & \multicolumn{4}{|c|}{ Public } & \multicolumn{4}{|c|}{ Private } \\
\hline & \multicolumn{2}{|l|}{ selection } & \multirow{2}{*}{ wage } & \multirow[b]{2}{*}{$* * *$} & \multicolumn{2}{|l|}{ selection } & \multicolumn{2}{|l|}{ wage } & \multicolumn{2}{|l|}{ election } & \multicolumn{2}{|l|}{ wage } & \multicolumn{2}{|c|}{ election } & \multicolumn{2}{|l|}{ wage } \\
\hline Constant & 4.304 & $* * *$ & & & 4.155 & $* * *$ & -0.927 & $* * *$ & -5.051 & $* * *$ & -2.803 & $* * *$ & 4.531 & $* * *$ & 1.499 & $* * *$ \\
\hline Age & 0.164 & $* * *$ & & & -0.154 & $* * *$ & & & 0.186 & $* * *$ & & & 0.164 & $* * *$ & & \\
\hline $\mathrm{Age}^{2}$ & 0.002 & $* * *$ & & & 0.001 & $* * *$ & & & 0.002 & $* * *$ & & & 0.002 & $* * *$ & & \\
\hline Experience & & & 0.057 & $* * *$ & & & 0.035 & $* * *$ & & & 0.051 & $* * *$ & & & 0.046 & $* * *$ \\
\hline Experience $^{2}$ & & & -0.001 & $* * *$ & & & -0.001 & $* * *$ & & & -0.0004 & $* * *$ & & & 0.0007 & $* * *$ \\
\hline \multicolumn{17}{|l|}{ Educational level } \\
\hline Read and Write & 0.719 & $* * *$ & 0.249 & $* * *$ & -0.726 & $* * *$ & 0.022 & & 0.994 & $* * *$ & 0.284 & $* * *$ & 0.700 & $* * *$ & -0.142 & \\
\hline Below intermediate & 1.003 & $* * *$ & 0.653 & $* * *$ & -1.022 & $* * *$ & 0.137 & $* * *$ & 1.621 & $* * *$ & 0.976 & $* * *$ & 1.273 & $* * *$ & 0.305 & $*$ \\
\hline Intermediate & 1.673 & $* * *$ & 1.030 & $* * *$ & -1.825 & $* * *$ & 0.286 & $* * *$ & 2.134 & $* * *$ & 1.182 & $* * *$ & 1.970 & $* * *$ & 0.369 & $* * *$ \\
\hline Higher Institute & 1.908 & $* * *$ & 1.271 & $* * *$ & -2.154 & $* * *$ & 0.240 & & 2.672 & $* * *$ & 1.348 & $* * *$ & 2.562 & $* * *$ & 0.747 & $* * *$ \\
\hline University & 1.418 & $* * *$ & 1.337 & $* * *$ & -1.570 & $* * *$ & 0.535 & $* * *$ & 2.059 & $* * *$ & 1.555 & $* * *$ & 1.884 & $* * *$ & 0.917 & $* * *$ \\
\hline Above University & 1.817 & $* * *$ & 1.899 & $* * *$ & -2.174 & $* * *$ & 0.678 & $*$ & 2.176 & $* * *$ & 2.058 & $* * *$ & & & & \\
\hline \multicolumn{17}{|l|}{ Region } \\
\hline Urban Lower Egypt & 0.156 & $* *$ & 0.038 & & -0.152 & $* *$ & -0.115 & $* * *$ & 0.541 & $* * *$ & 0.040 & & 0.612 & $* * *$ & -0.038 & \\
\hline Rural Lower Egypt & 0.239 & $* * *$ & -0.040 & $*$ & -0.201 & $* * *$ & -0.103 & $* * *$ & 0.406 & $* * *$ & 0.093 & $* * *$ & 0.133 & & 0.003 & \\
\hline Urban Upper Egypt & 0.296 & $* * *$ & 0.082 & $* * *$ & -0.292 & $* * *$ & -0.134 & $* * *$ & 0.679 & $* * *$ & 0.142 & $* * *$ & 0.779 & $* * *$ & -0.260 & \\
\hline Rural Upper Egypt & 0.010 & & -0.082 & $* * *$ & 0.085 & * & -0.123 & $* * *$ & 0.690 & $* * *$ & 0.170 & $* * *$ & 0.687 & $* * *$ & 0.331 & * \\
\hline \multicolumn{17}{|l|}{ Job Characteristics } \\
\hline Minining & & & 0.448 & $* * *$ & & & 0.512 & $* * *$ & & & 0.342 & & & & & \\
\hline Manufacturing & & & 0.065 & $* * *$ & & & -0.053 & & & & 0.139 & & & & -0.052 & \\
\hline Electricity, Gas \& Water & & & -0.062 & & & & 0.167 & & & & 0.004 & & & & & \\
\hline Construction & & & 0.169 & $* * *$ & & & 0.288 & $* * *$ & & & 0.227 & & & & 0.258 & \\
\hline Trade & & & 0.102 & $* * *$ & & & -0.146 & $* * *$ & & & 0.057 & & & & -0.302 & * \\
\hline Transport & & & 0.031 & & & & 0.115 & $* * *$ & & & 0.084 & & & & -0.092 & \\
\hline Finance & & & 0.135 & $* *$ & & & -0.042 & & & & 0.145 & & & & -0.254 & \\
\hline Social Services & & & -0.068 & $* *$ & & & -0.269 & $* * *$ & & & 0.048 & & & & -0.512 & $* * *$ \\
\hline Casual Work & & & 0.369 & $*$ & & & 0.034 & & & & -0.310 & & & & 0.026 & \\
\hline \multicolumn{17}{|l|}{ ousehold Characteristics } \\
\hline Household Head & 0.041 & & & & 0.116 & $*$ & & & & & & & & & & \\
\hline ale Public Employee in the & & & & & & & & & & & & & & & & \\
\hline Household & & & & & & & & & 0.329 & $* * *$ & & & 0.495 & $* * *$ & & \\
\hline Married & 0.086 & & & & -0.093 & & & & 0.010 & & & & 0.315 & $* * *$ & & \\
\hline Sector Selection Term & & & 0.372 & $* * *$ & & & -0.021 & & & & 0.253 & $* * *$ & & & 0.018 & $* * *$ \\
\hline Sample Size & & & & 309 & & & & & & & 179 & & & & & \\
\hline Log Likelihood & -1113.428 & & & & -1508.25 & & & & 59.812 & & & & .918 & & & \\
\hline Goodness of Fit -- $c^{2}(36)$ & 324.410 & & & & 2219.36 & & & & 60.010 & & & & .520 & & & \\
\hline$\left(\operatorname{Prob}>\mathrm{c}^{2}\right)$ & $(0.000)$ & & & & $(0.000)$ & & & & $(0.000)$ & & & & 000) & & & \\
\hline
\end{tabular}

Source: Authors calculation, based on CAPMAS, 1987 LFSS.

Notes: * denotes significance at the 10 percent level, $* *$ denotes significance at the five percent level and $* *$ denotes significance at the 1 percent level. The goodness of fit is a log-likelihood ratio test of the null hypothesis that the parameters of the model are jointly equal to zero 
Table 2. Maximum Likelihood (Probit) Estimates of the Selection and Wage Equations 1997

\begin{tabular}{|c|c|c|c|c|c|c|c|c|c|c|c|c|c|c|c|c|}
\hline \multirow{3}{*}{ Variable } & \multicolumn{8}{|c|}{ MALES } & \multicolumn{8}{|c|}{ FEMALES } \\
\hline & \multicolumn{4}{|c|}{ Public } & \multicolumn{4}{|c|}{ Private } & \multicolumn{4}{|c|}{ Public } & \multicolumn{4}{|c|}{ Private } \\
\hline & selection & & wage & & selection & & wage & & selection & & wage & & Selection & & wage & \\
\hline Constant & -6.001 & $* * *$ & -1.508 & $* * *$ & 2.800 & $* * *$ & -0.900 & $* * *$ & -4.470 & $\begin{array}{l}* \\
* *\end{array}$ & -0.864 & $* * *$ & 1.550 & $* * *$ & -1.390 & $* * *$ \\
\hline Age & 0.201 & $* * *$ & & & -0.069 & $* * *$ & & & 0.156 & $\begin{array}{l}* \\
* * \\
*\end{array}$ & & & -0.015 & $* * *$ & & \\
\hline Age2 & -0.002 & $* * *$ & & & 0.001 & $* * *$ & & & -0.001 & * & & & -0.0001 & $* * *$ & & \\
\hline Experience & & & 0.045 & $* * *$ & & & 0.041 & $* * *$ & & & 0.044 & $* * *$ & & & 0.037 & $* *$ \\
\hline Experience2 & & & -0.037 & $* * *$ & & & -0.049 & $* * *$ & & & -0.049 & $* * *$ & & & -0.066 & $* *$ \\
\hline $\begin{array}{l}\text { Educational level } \\
\text { less than Primary }\end{array}$ & 0.392 & $* * *$ & 0.246 & $* *$ & -0.319 & $* * *$ & 0.117 & $*$ & $(.356)$ & & -0.387 & $*$ & -0.603 & $* * *$ & -0.573 & $* *$ \\
\hline Primary & 0.859 & $* * *$ & 0.257 & $* *$ & -0.635 & $* * *$ & 0.250 & $* * *$ & 0.867 & $* *$ & -0.203 & $* * *$ & -0.728 & $* * *$ & -0.266 & \\
\hline Preparatory & 0.860 & $* * *$ & 0.538 & $* * *$ & -0.958 & $* * *$ & 0.311 & $* * *$ & 0.117 & & -0.233 & & -0.893 & $* * *$ & -0.105 & \\
\hline General Secondary & 0.786 & $* * *$ & 1.098 & $* * *$ & -1.260 & $* * *$ & -0.089 & & 0.883 & $* *$ & 0.203 & & -0.111 & $* * *$ & 0.792 & $*$ \\
\hline Vocational Secondary & 0.984 & $* * *$ & 0.705 & $* * *$ & -0.791 & $* * *$ & 0.256 & $* * *$ & 1.510 & $\begin{array}{l}* \\
* * \\
*\end{array}$ & 0.105 & & -1.620 & $* * *$ & -0.833 & $* * *$ \\
\hline Higher Institute & 1.600 & $* * *$ & 0.751 & $* * *$ & -1.500 & $* * *$ & 0.500 & $* * *$ & 1.270 & $\begin{array}{l}* \\
* *\end{array}$ & 0.273 & & -1.028 & $* * *$ & -0.040 & \\
\hline University & 1.270 & $* * *$ & 1.060 & $* * *$ & -1.039 & $* * *$ & 0.834 & $* * *$ & 1.510 & $\begin{array}{l}* \\
* * \\
*\end{array}$ & 0.504 & $* * *$ & -1.709 & $* * *$ & -0.340 & \\
\hline $\begin{array}{l}\text { Other } \\
\text { Region }\end{array}$ & 1.770 & $* * *$ & 1.260 & $* * *$ & -1.210 & $* * *$ & 0.112 & & 1.140 & * & 0.238 & & -1.855 & $* * *$ & -0.391 & \\
\hline & & & & & & & & & & $* *$ & & & & & & \\
\hline Urban Lower Egypt & 0.177 & & -0.074 & & -0.123 & & -0.035 & & 0.627 & $*$ & 0.039 & & -0.780 & $* * *$ & -0.903 & $* * *$ \\
\hline Rural Lower Egypt & 0.268 & $* *$ & -0.009 & & -0.198 & $* *$ & 0.766 & & 0.362 & $\begin{array}{l}* \\
* *\end{array}$ & -0.100 & & -0.389 & $* * *$ & 0.054 & \\
\hline Urban Upper Egypt & 0.345 & $* * *$ & 0.167 & $* * *$ & -0.193 & $*$ & 0.149 & $* *$ & 0.588 & * & -0.069 & & -0.288 & $* * *$ & -0.611 & $* * *$ \\
\hline $\begin{array}{l}\text { Rural Upper Egypt } \\
\text { Job Characteristics }\end{array}$ & -0.038 & & -0.075 & $* * *$ & -0.184 & $*$ & 0.062 & & 0.353 & & 0.056 & & -0.651 & $* * *$ & -0.169 & \\
\hline Minining & & & 0.620 & $* * *$ & & & & & & & & & & & & \\
\hline Manufacturing & & & 0.295 & $* * *$ & & & -0.100 & & & & 0.171 & & & & 0.183 & \\
\hline Electricity, Gas \& Water & & & 0.197 & & & & 0.922 & & & & 0.144 & & & & & \\
\hline Construction & & & 0.289 & $* * *$ & & & 0.113 & $*$ & & & 0.082 & & & & 0.328 & \\
\hline Trade & & & 0.224 & & & & -0.117 & & & & 0.398 & & & & -0.022 & \\
\hline Transport & & & 0.226 & $* *$ & & & 0.291 & & & & 0.034 & & & & 0.680 & $* * *$ \\
\hline Finance & & & 0.312 & $* *$ & & & -0.427 & $* *$ & & & 0.354 & $*$ & & & 1.120 & $* * *$ \\
\hline Social Services & & & 0.152 & $*$ & & & -0.060 & & & & 0.877 & $* * *$ & & & -0.070 & \\
\hline $\begin{array}{l}\text { Casual Work } \\
\text { Background } \\
\text { Characteristics }\end{array}$ & & & 0.152 & $* *$ & & & -0.185 & $* * *$ & & & 0.015 & & & & 0.228 & $* *$ \\
\hline $\begin{array}{l}\text { Risk Aversion Index } \\
\text { Male Public Emp. in the }\end{array}$ & 0.227 & $* * *$ & & & -0.212 & * & & & & & & & & $* * *$ & & \\
\hline Household & & & & & & & & & 0.298 & $* *$ & & & -0.332 & $* * *$ & & \\
\hline Father Highly Educated & 0.315 & $* * *$ & & & -0.262 & & & & -0.151 & & & & -0.023 & $* * *$ & & \\
\hline Father Salaried & 0.087 & & & & -0.140 & $*$ & & & 0.308 & $* *$ & & & -0.127 & $* * *$ & & \\
\hline Sector Selection Term & & & 0.002 & & & & 0.063 & $* * *$ & & & -0.083 & & & & 0.803 & $* * *$ \\
\hline Sample Size & & 72 & & & & & & & & & & & & 17 & & \\
\hline Log Likelihood & & 2.14 & & & & -56 & & & & & 84.24 & & & & -742.90 & \\
\hline $\begin{array}{l}\text { Goodness of Fit }-c^{2}(36) \\
\left(\text { Prob }>c^{2}\right)\end{array}$ & & & & & & $\begin{array}{l}36 \\
(0 .\end{array}$ & & & & & $\begin{array}{l}.810 \\
000)\end{array}$ & & & & $\begin{array}{l}183.840 \\
(0.000)\end{array}$ & \\
\hline
\end{tabular}

Source: Author's calculation based on IFPRI, 1997 EIHS 
Table 3. Estimated Mean Public-Private Wage Differentials by Educational Level, 1987 and 1997

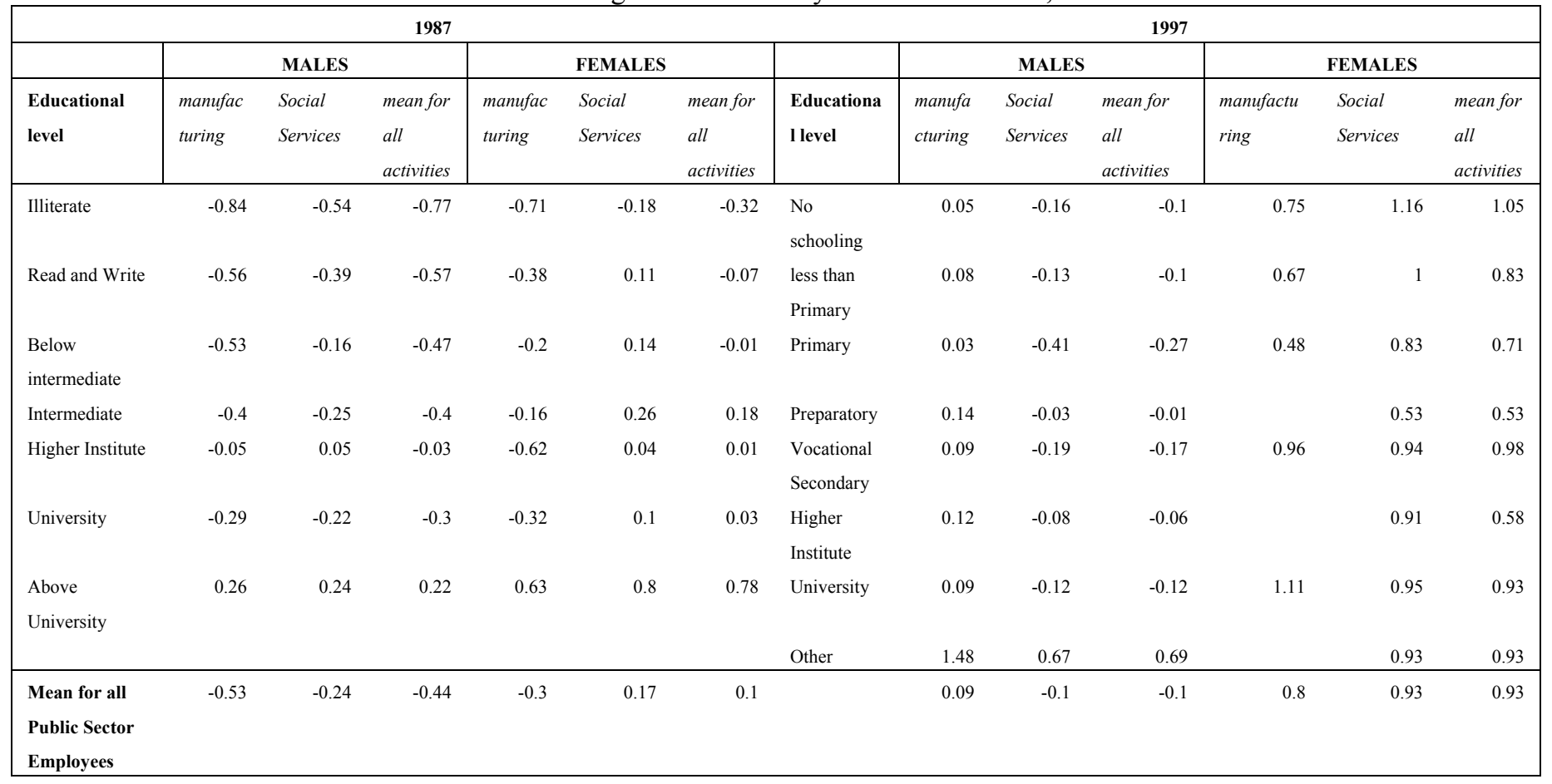

Source: CAPMAS, 1987 LFSS and IFPRI 1997 EIHS 
Table 4. Estimates of Determinants of Second Job Holding and Males in the Private Sector Compensating Differentials Equation, 1997

\begin{tabular}{|c|c|c|c|c|c|c|c|c|c|c|}
\hline \multirow{3}{*}{ Variable } & \multicolumn{6}{|c|}{ Determinants of Second Job Holding Equation } & \multirow[b]{2}{*}{ Variable } & \multicolumn{3}{|c|}{\begin{tabular}{|c|} 
Private Sector Males \\
Compensating Differentials \\
Equation
\end{tabular}} \\
\hline & \multicolumn{3}{|c|}{ Probit estimates } & \multicolumn{3}{|c|}{ Marginal estimates } & & & & \\
\hline & Coefficien & & $\begin{array}{l}\text { Standard } \\
\text { error }\end{array}$ & Coefficient & & $\begin{array}{l}\text { Standard } \\
\text { error }\end{array}$ & & Coefficie & & $\begin{array}{l}\text { Standard } \\
\text { error }\end{array}$ \\
\hline Age & 0.048 & $* * *$ & 0.016 & 0.007 & $* * *$ & 0.003 & Experience & 0.039 & $* * *$ & 0.004 \\
\hline Age2 & -0.001 & $* * *$ & 0.000 & -0.000 & $* * *$ & 0.000 & Experience2 & -0.048 & $* * *$ & 0.006 \\
\hline Years of Schooling & -0.026 & $* * *$ & 0.007 & -0.004 & $* * *$ & 0.001 & Less than Primary & 0.093 & $*$ & 0.048 \\
\hline Female & -0.754 & $* * *$ & 0.131 & -0.083 & $* * *$ & 0.010 & $\begin{array}{l}\text { Primary } \\
\text { Preparatory } \\
\text { General Secondary }\end{array}$ & $\begin{array}{l}0.197 \\
0.277 \\
0.153\end{array}$ & $* * *$ & $\begin{array}{l}0.056 \\
0.082 \\
0.153\end{array}$ \\
\hline Urban Lower Egypt & 0.291 & $* *$ & 0.146 & 0.052 & $* *$ & 0.029 & Vocational Secondary & 0.441 & $* * *$ & 0.061 \\
\hline Rural Lower Egypt & 0.453 & $* * *$ & 0.131 & 0.081 & $* * *$ & 0.026 & Higher Institute & 0.376 & $* *$ & 0.174 \\
\hline Urban Upper Egypt & 0.000 & & 0.153 & 0.000 & & 0.024 & University & 0.799 & $* * *$ & 0.094 \\
\hline Rural Upper Egypt & 0.154 & & 0.138 & 0.025 & & 0.024 & Other & 0.038 & & 0.242 \\
\hline Manufacturing & -0.949 & $* * *$ & 0.125 & -0.099 & $* * *$ & 0.009 & Job Instability & 0.509 & $* * *$ & 0.188 \\
\hline Electricity, Gas \& Water & -0.570 & $* * *$ & 0.207 & -0.061 & $* * *$ & 0.014 & Probability of Second Job Holding & -1.360 & $* *$ & 0.583 \\
\hline Construction & -0.886 & $* * *$ & 0.146 & -0.085 & $* * *$ & 0.009 & Fringe Benefits & -0.119 & $* *$ & 0.058 \\
\hline Trade & -0.809 & $* * *$ & 0.221 & -0.075 & $* * *$ & 0.011 & & & & \\
\hline Transport & -1.118 & $* * *$ & 0.197 & -0.089 & $* * *$ & 0.008 & Constant & -0.758 & $* * *$ & 0.097 \\
\hline Finance & -0.781 & $* * *$ & 0.337 & -0.071 & $* * *$ & 0.015 & & & & \\
\hline Social Services & -0.583 & $* * *$ & 0.108 & -0.083 & $* * *$ & 0.014 & & & & \\
\hline Public Sector Employee & 0.454 & $* * *$ & 0.099 & 0.072 & $* * *$ & 0.016 & & & & \\
\hline Constant & -1.722 & $* * *$ & 0.318 & & & & & & & \\
\hline Sample Size & 2563 & & & & & & Sample Size & 1057 & & \\
\hline Log Likelihood & -803.990 & & & & & & $\mathbf{R} 2$ & 0.150 & & \\
\hline $\begin{array}{l}\text { Goodness of Fit }-c^{2}(19) \\
\left(\operatorname{Prob}>c^{2}\right)\end{array}$ & $\begin{array}{l}567.000 \\
(0.000)\end{array}$ & & & & & & & & & \\
\hline
\end{tabular}

Source: Author's calculation based on IFPRI, 1997 EIHS.

Notes: * denotes significance at the 10 percent level, ${ }^{* *}$ denotes significance at the five percent level and $* *$ denotes significance at the 1 percent level.

Table 5. Male Public-Private Wage Differentials Adjusted for Non-pecuniary Aspects, 1997

\begin{tabular}{|c|c|c|c|c|c|c|c|c|c|c|c|c|c|c|c|c|}
\hline \multirow[t]{3}{*}{ Educational level } & \multicolumn{5}{|c|}{ Manufacturing } & \multicolumn{5}{|c|}{ Social Services } & \multicolumn{6}{|c|}{ Mean For All Activities } \\
\hline & UAD & $F B$ & $P S J$ & INS & $A D 1$ & $U A D$ & $F B$ & $P S J$ & INS & $A D 1$ & $U A D$ & $F B$ & $P S J$ & INS & $A D 1$ & $A D 2$ \\
\hline & \multicolumn{5}{|c|}{ (in log hourly wages) } & \multicolumn{5}{|c|}{ (in log hourly wages) } & \multicolumn{6}{|c|}{ (in log hourly wages) } \\
\hline No schooling & 0.08 & 0.09 & 0.10 & 0.18 & 0.45 & -0.13 & 0.09 & 0.10 & 0.15 & 0.22 & -0.07 & 0.11 & 0.10 & 0.24 & 0.37 & \\
\hline less than Primary & 0.07 & 0.09 & 0.10 & 0.17 & 0.43 & -0.05 & 0.11 & 0.10 & 0.12 & 0.28 & -0.06 & 0.10 & 0.10 & 0.21 & 0.35 & \\
\hline Primary & 0.01 & 0.11 & 0.10 & 0.17 & 0.39 & -0.24 & 0.07 & 0.10 & 0.14 & 0.07 & -0.18 & 0.10 & 0.10 & 0.20 & 0.22 & \\
\hline Preparatory & 0.12 & 0.08 & 0.10 & 0.17 & 0.46 & -0.03 & 0.12 & 0.10 & 0.12 & 0.31 & -0.01 & 0.10 & 0.10 & 0.18 & 0.37 & \\
\hline Vocational Secondary & 0.08 & 0.06 & 0.10 & 0.15 & 0.39 & -0.16 & 0.08 & 0.10 & 0.12 & 0.14 & -0.14 & 0.09 & 0.10 & 0.19 & 0.24 & \\
\hline Higher Institute & 0.11 & 0.12 & 0.10 & 0.16 & 0.49 & -0.05 & 0.12 & 0.10 & 0.11 & 0.27 & -0.03 & 0.10 & 0.10 & 0.18 & 0.35 & \\
\hline University & 0.11 & 0.03 & 0.10 & 0.14 & 0.39 & -0.10 & 0.05 & 0.10 & 0.10 & 0.15 & -0.09 & 0.06 & 0.10 & 0.15 & 0.22 & \\
\hline Other & 1.04 & 0.12 & 0.10 & 0.12 & 1.37 & 0.79 & 0.00 & 0.10 & 0.09 & 0.98 & 0.82 & 0.10 & 0.10 & 0.17 & 1.18 & \\
\hline \multirow{3}{*}{\multicolumn{17}{|c|}{$\begin{array}{l}\text { Mean Differential for } \\
\text { all Male Public Sector } \\
\text { Employees }\end{array}$}} \\
\hline & & & & & & & & & & & & & & & & \\
\hline & & & & & & & & & & & & & & & & \\
\hline in log hourly wages & 0.10 & 0.08 & 0.10 & 0.16 & 0.44 & -0.06 & 0.09 & 0.10 & 0.13 & 0.25 & -0.05 & 0.10 & 0.10 & 0.21 & 0.35 & \\
\hline as $\%$ of public wage & $10 \%$ & $10 \%$ & $13 \%$ & $22 \%$ & $45 \%$ & $-10 \%$ & $8 \%$ & $8 \%$ & $11 \%$ & $27 \%$ & $-10 \%$ & $14 \%$ & $14 \%$ & $31 \%$ & $42 \%$ & $57 \%$ \\
\hline
\end{tabular}

Source: Author's calculation based on IFPRI, 1997 EIHS. 


\section{A. Males, 1987}

- Public
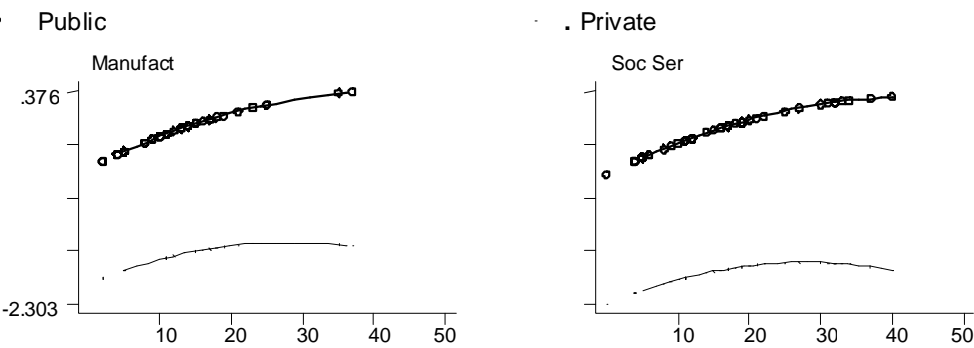

\section{B. Females, 1987}

- Public

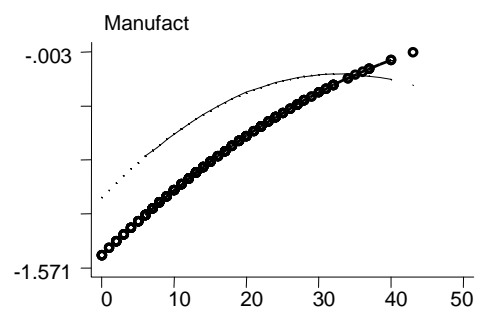

. Private

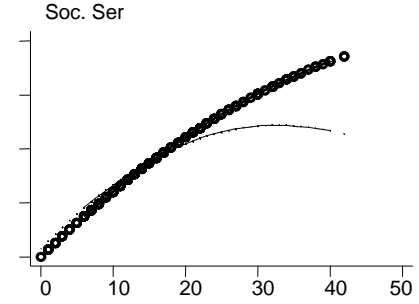

\section{Males, 1997}

- Public

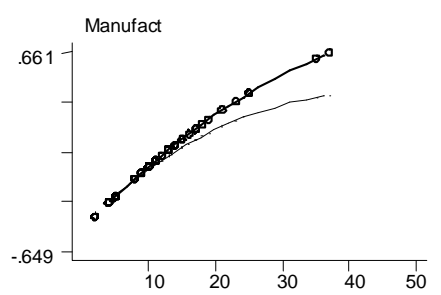

. Private

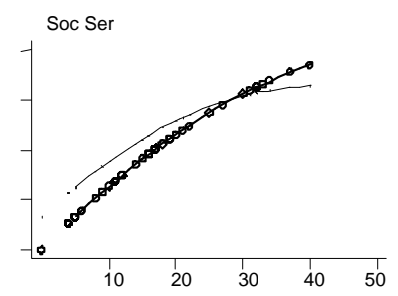

D. Females, 1997

- Public

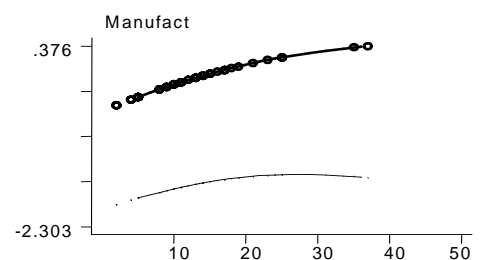

. Private

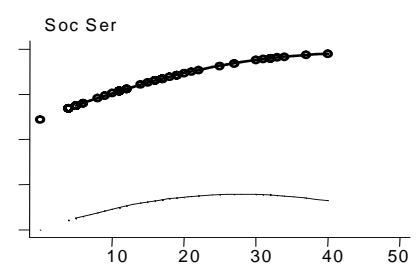

Figure 1. Estimated Wage-Experience Profiles 